\title{
30. SUMMARY OF CHRONOSTRATIGRAPHIC STUDIES, DEEP SEA DRILLING PROJECT LEG 96
}

\author{
Barry Kohl, Douglas F. Williams, Michael T. Ledbetter, Richard E. Constans, John W. King, Linda E. Heusser, \\ Claudia Schroeder, and Joseph J. Morley²
}

\begin{abstract}
At all sites drilled during Deep Sea Drilling Project Leg 96, we penetrated late Quaternary sediments, encountering Ericson Zones W, X, Y, and Z (early Wisconsin glacial through Holocene).

Chronostratigraphic studies on the Mississippi Fan were limited to foraminifer and calcareous nannofossil biostratigraphy because of very high sedimentation rates $(6-11 \mathrm{~m} / 1000 \mathrm{yr})$.

The main focus of interdisciplinary stratigraphic studies was Site 619 in the Pigmy Basin. At Site 619, an almost continuous sequence of hemipelagic sediments was recovered from Ericson Zones X through Z. Detailed studies at this site include: biostratigraphy (foraminifers, calcareous nannofossils, palynology), oxygen-isotope stratigraphy, tephrochronology, and magnetostratigraphy. Comparison of the curves shows a close correlation between biostratigraphy, oxygenisotope stages, and tephrochronology.
\end{abstract}

\section{INTRODUCTION}

This chapter summarizes the biostratigraphy, oxygenisotope stratigraphy, tephrochronology, and magnetostratigraphy results for Deep Sea Drilling Project (DSDP) Leg 96. A total of 11 sites were cored in the Gulf of Mexico. Nine of the sites (Sites 614-617 and 620-624) are located on the Mississippi Fan; the other two sites (Sites 618 and 619) are positioned in intraslope basins on the Louisiana continental slope (Fig. 1).

The zonation for the late Quaternary that was used on Leg 96 is shown in Figure 2. The framework used for foraminifers was proposed by Ericson and Wollin (1968) and expanded by Kennett and Huddlestun (1972). Calcareous nannofossil zonation is based on studies by Gartner and Emiliani (1976), Boudreaux and Hay (1967), and Thierstein et al. (1977); the oxygen-isotope stratigraphy refers to the work of Williams (1984).

Shipboard dating of the Quaternary cores was restricted to foraminifers and calcareous nannofossils. In addition, several other chronostratigraphic disciplines were incorporated during post-cruise evaluation to determine correlation or paleoclimatology (Fig. 3). The results of these studies indicate that cores at all Leg 96 sites penetrated Ericson Zone Y (late Wisconsin glacial); the oldest section recovered was Ericson Zone W (early Wisconsin glacial) at Site 615 (Fig. 4 and Site 615 chapter, this volume).

\footnotetext{
${ }^{1}$ Bouma, A. H., Coleman, J. M., Meyer, A. W., et al., Init. Repts. DSDP, 96: Washington (U.S. Govt. Printing Office).

2 Addresses: (Kohl, Constans) Chevron USA, 935 Gravier St., New Orleans, LA 70112, (Williams) Department of Geology, University of South Carolina, Columbia, SC 29208; (Ledbetter) Moss Landing Marine Laboratories, P.O. Box 450, Moss Landing, CA 95029; (King) Graduate School of Oceanography, University of Rhode Island, Narragansett, RI 02882 (Heusser, Morley) Lamont-Doherty Geological Observatory, Columbia University, Palisades, NY 10964; (Schroeder) Department of Geology, Dalhousie University, Halifax, Nova Scotia B3H 3 J5.
}

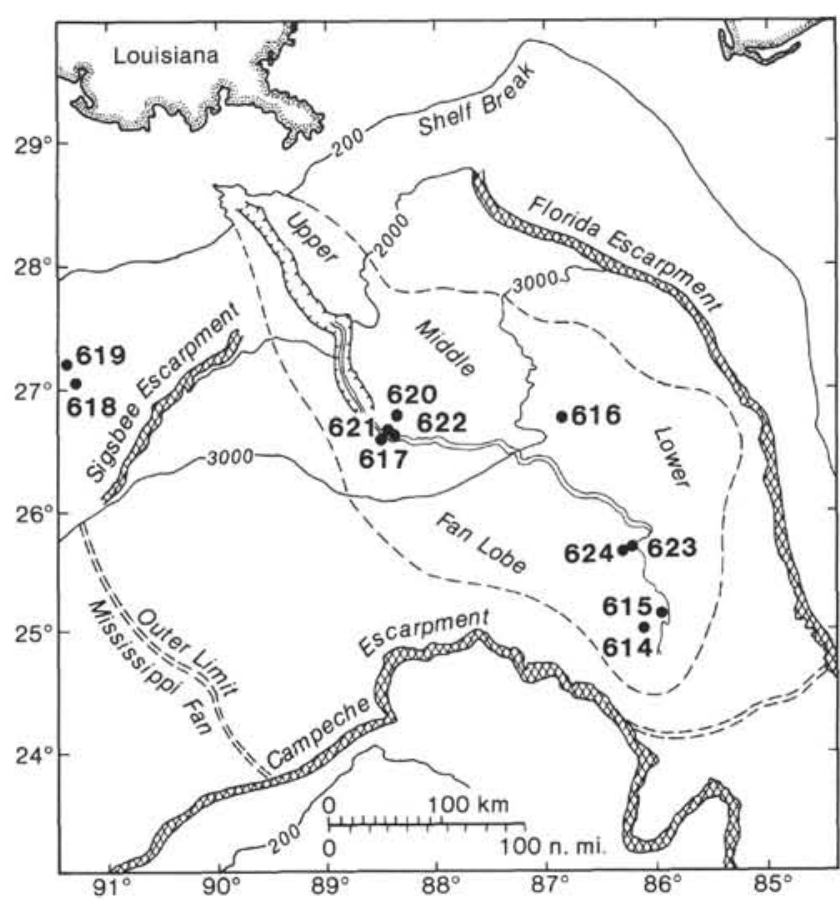

Figure 1. Location map of Leg 96 sites.

\section{MISSISSIPPI FAN}

Drill sites on the Mississippi Fan are mainly concentrated in two regions. Sites 617 and 620 through 622 are located in or adjacent to the middle-fan channel complex; Site 616 is located on the margin of the middle-fan region. Sites 614 and 615 together with Sites 623 and 624 are located on the lower fan. Very high sedimentation rates $(6-11 \mathrm{~m} / 1000 \mathrm{yr}$.) at these sites presented unique correlation problems. Subdivision of the Pleistocene was complicated by extensive dilution of the foraminifer fau- 


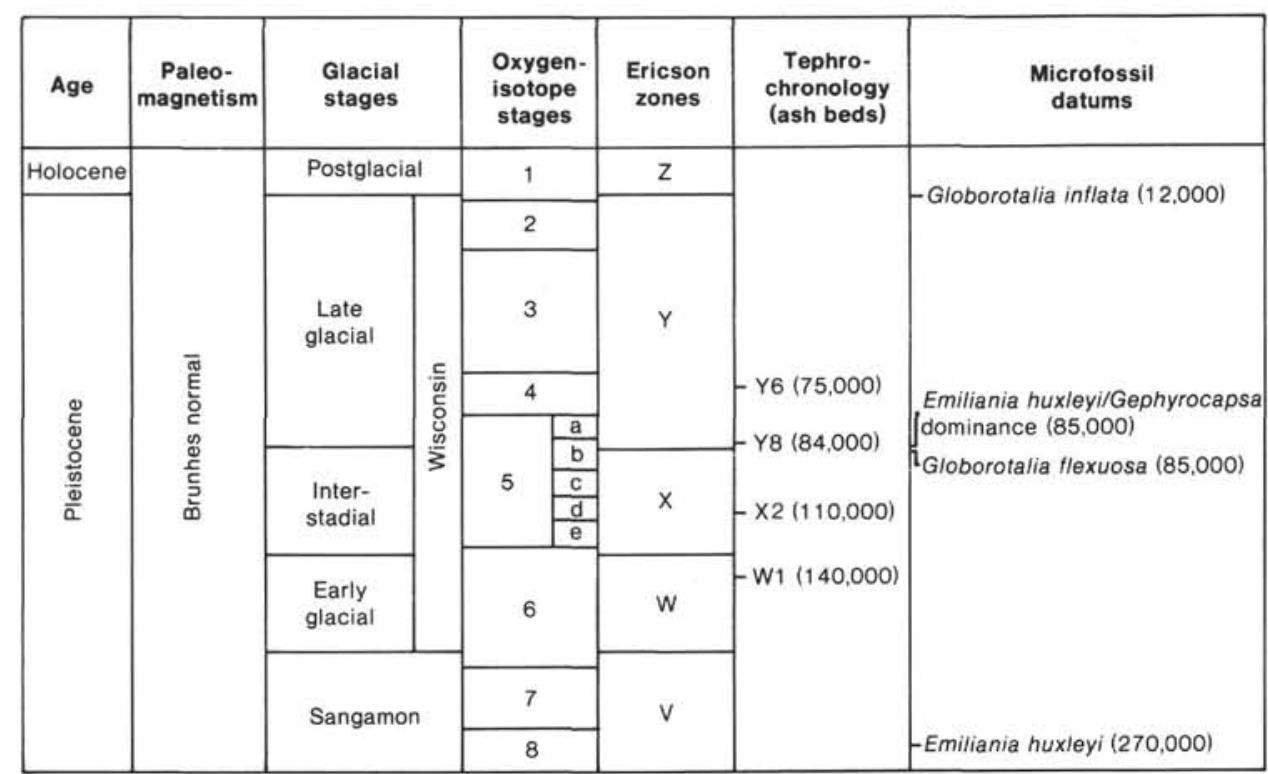

Figure 2. Late Quaternary zonation for the Gulf of Mexico. After Rabek et al. (1985), Williams (1984), Thierstein et al. (1977), Ericson and Wollin (1968). Dates shown in the two right-hand columns are in years before present.

\begin{tabular}{|c|c|c|c|c|c|c|c|c|}
\hline$\stackrel{\Xi}{\omega}$ & 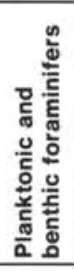 & 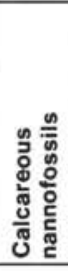 & 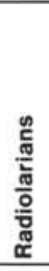 & 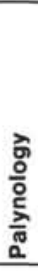 & 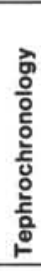 & 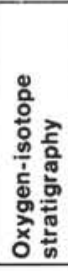 & 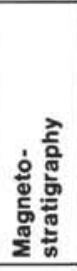 & 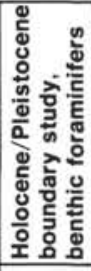 \\
\hline 614 & $\mathrm{x}$ & $x$ & $x$ & & & & & \\
\hline 615 & $x$ & $x$ & $x$ & $x$ & $x$ & & & \\
\hline 616 & $x$ & $x$ & & $x$ & & & & \\
\hline 617 & $x$ & $x$ & & & & & & \\
\hline 618 & $x$ & $x$ & $x$ & $x$ & & & $x$ & \\
\hline 619 & $x$ & $x$ & $x$ & $x$ & $x$ & $x$ & $x$ & $x$ \\
\hline 620 & $x$ & $x$ & & $x$ & & $x$ & & $x$ \\
\hline 621 & $x$ & $x$ & & & & & & $x$ \\
\hline 622 & $x$ & $x$ & $x$ & & & & & $x$ \\
\hline 623 & $x$ & $x$ & $x$ & & & & & \\
\hline 624 & $x$ & $x$ & & & & & & $x$ \\
\hline
\end{tabular}

Figure 3. Summary of chronostratigraphic studies completed at Leg 96 sites. Data for planktonic and benthic foraminifers and calcareous nannofossils are from shipboard studies; other data are from shore-based studies. Data are presented in this volume as follows: foraminifers (site chapters, this volume; Kohl, this volume; Schroeder, this volume), calcareous nannofossils (site chapters, this volume; Constans and Parker, this volume), radiolarians (Morley and Kohl, this volume), palynology (Heusser, this volume), tephrochronology (Ledbetter, this volume), oxygen isotopes (Williams and Kohl, this volume), and magnetostratigraphy (King, this volume).

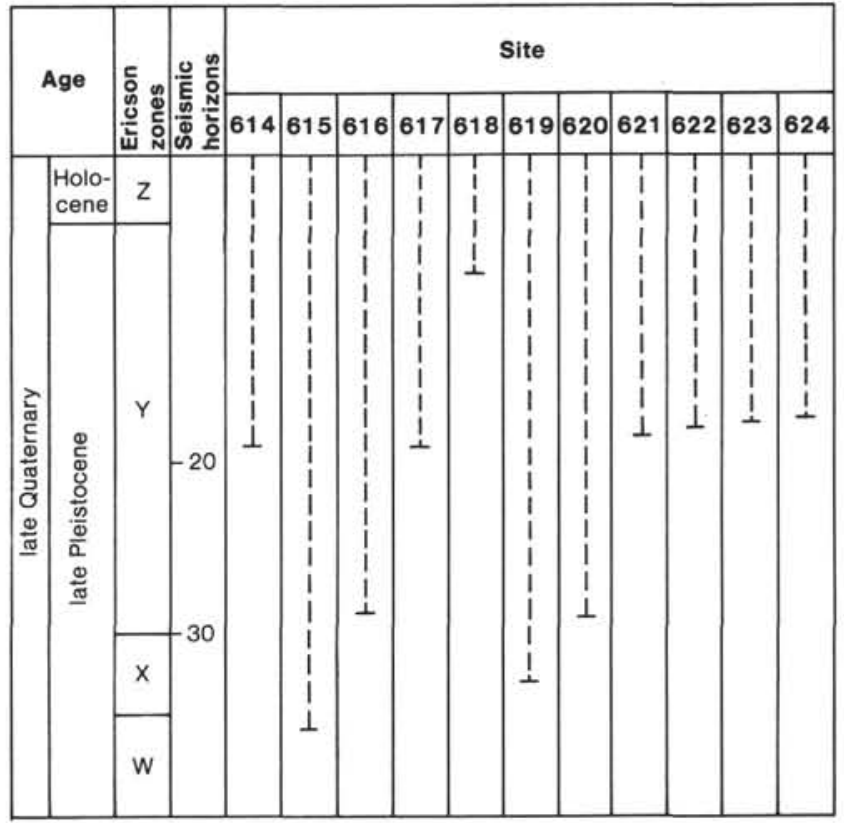

Figure 4. Age of the 11 sites cored during Leg 96 (not to scale). Depths in Zone $\mathrm{Y}$ are related to seismic Horizons 20 and 30 (Stelting, Bouma, and Coleman, this volume).

na and calcareous nannofossil flora by reworked terrigenous clastic sediment.

All fan sites except Site 615 terminated in the late Wisconsin glacial (Ericson Zone Y). Site 615 was drilled through Zones $\mathrm{Z}$, $\mathrm{Y}$, and $\mathrm{X}$ and bottomed in early Wisconsin glacial (Zone W) sediments (see Site 615 chapter, this volume).

Correlation between most fan sites was accomplished using planktonic and benthic foraminifers. Local zones of tasmanitids, Quaternary radiolarians, and reworked 
Cretaceous foraminifers and radiolarians were often useful in correlation (Kohl et al., 1985).

The in situ/reworked ratio of calcareous nannofossils is used as an index of the degree of reworking at Leg 96 sites. The generated curve can be used to correlate between some Mississippi Fan sites (Constans and Parker, this volume). Interstadial and post-glacial intervals (Zones $\mathrm{X}$ and $\mathrm{Z}$ ) have high concentrations of Pleistocene in situ flora while the glacial intervals (Zones W and Y) are dominated by reworked Cretaceous nannofossils (see Constans and Parker and Site 615 chapter, this volume).

The high dilution of Pleistocene fossils by terrigenous sediments prohibited detailed studies of other fossil groups at the fan sites. Quaternary radiolarians recovered from Holocene and latest Pleistocene sediments are extremely rare and therefore cannot be used for quantitative analysis (Morley and Kohl, this volume).

Spore and pollen studies also reveal large amounts of reworked Cretaceous and Tertiary forms. Concentrations of pollen are low because of dilution by terrigenous clastics (Heusser, this volume).

Dilution and reworking prevented tephrochronology studies at eight of the nine sites. One location, Site 615, contains a zone of dispersed ash between 171 and $195 \mathrm{~m}$ sub-bottom, but attempts at tephrochronology proved inconclusive (M. Ledbetter, personal communication, 1985).

Studies of benthic foraminifer assemblages across the Holocene/Pleistocene boundary (Schroeder, this volume) show a downhole decrease in benthic species diversity that was used to determine the Holocene/Pleistocene transition zone at four of the Mississippi Fan sites. Results of benthic foraminifer studies were utilized in conjunction with planktonic foraminifers at Sites $620,621,622$, and 624 to refine the Zone Z/Y boundary of Ericson and Wollin (1968).

\section{INTRASLOPE BASINS}

\section{Orca Basin}

Orca Basin (Site 618), an anoxic interdomal-type intraslope basin (see Intraslope Basin Introduction and Summary, this volume), was the primary site originally selected to core a complete and undisturbed late Quaternary section. However, extensive slumping observed in the recovered cores resulted in the abandonment of the program at the Orca Basin locality. Instead, it was decided that the project be moved to the Pigmy Basin.

\section{Pigmy Basin}

Pigmy Basin (Site 619), a blocked-canyon type intraslope basin, has relatively undisturbed sediments for both chronostratigraphic studies and correlation of lithologies with vertical seismic sequences (Bouma, Stelting, et al., this volume). Because sedimentation rates $(1.9 \mathrm{~m} / 1000$ yr. during Ericson Zone $\mathrm{Y})$ were much lower at this site than at the Mississippi Fan sites, the cores were extensively sampled for evaluation by the various chronostratigraphic disciplines (Fig. 3).

Planktonic foraminifers are common to abundant at Site 619 and give a fairly reliable paleoclimatic record for Ericson Zones X through Z (Kohl, this volume). Fig- ure 5 shows a planktonic foraminifer curve derived from the cool- and warm-water faunas recovered from Site 619. Below $157 \mathrm{~m}$ sub-bottom, displaced faunas and a decrease in core recovery make quantitative studies difficult. These displaced sediments appear to have been derived from the Louisiana continental shelf when the basin was open to bottom-sediment transport (Kohl, this volume). Although the age of the interval from $157 \mathrm{~m}$ to total depth $(208.7 \mathrm{~m})$ is questionable, it is tentatively assigned to Ericson Zone X.

Oxygen-isotope stages (Fig. 5) correlate with the foraminifer biostratigraphy: isotope Stages 1, 3 and the upper part of 5 represent interstadials and Stages 2 and 4 represent glacial periods. The isotope peaks of $-2.0 \% 0$ indicated probable meltwater spikes; these peaks may represent the influx of significant quantities of fresh water into the Gulf of Mexico (Williams and Kohl, this volume).

Tephrochronology proved to be a very valuable link between biostratigraphy and oxygen-isotope stratigraphy at Site 619. An ash layer approximately $3 \mathrm{~cm}$ thick occurs at $142 \mathrm{~m}$ sub-bottom and is identified by major-element chemistry as the Y8 ash (Fig. 5 and Ledbetter, this volume). Two other dispersed ashes were identified tentatively as the Y6 and X2 ash, deposited 75,000 and 110,000 yr. ago, respectively (Fig. 2). Good correlation exists between the ash layers, foraminifer biostratigraphy, and the oxygen-isotope stages.

Calcareous nannofossil zonation for Site 619 is also presented in Figure 5. Because reworked Cretaceous nannofossils are common at this site, Constans and Parker (this volume) use the in situ/reworked ratio curve as an indicator of the relative amount of terrigenous clastics entering the Pigmy Basin. The greatest reworking and clastic input took place in Ericson Zone Y (late Wisconsin glacial), whereas the most abundant in situ nannofossils are found in Ericson Zone X and Z (Wisconsin interstadial and postglacial).

The percentage of total carbonate in the $<63 \mu \mathrm{m}$ fraction is shown in Figure 5. Williams and Kohl (this volume) suggest that some of the peaks are related to meltwater events and these may represent influxes of terrigenous carbonate possibly in the form of reworked Cretaceous nannofossils. However, this interpretation is complicated by increases in biogenic carbonate during warm intervals.

Heusser (this volume) reports that Site 619 sediments contain significant amounts of reworked palynomorphs. These appear to be more prevalent in the glacial intervals. Three pollen curves are presented in Figure 5: boreal conifers (spruce, hemlock, and fir) are more abundant during the glacial episodes, and oak pollen is more abundant in the interglacial sediments; pine pollen occurs in both warm and cool cycles.

The major goal of the rock-magnetic study at Site 619 is to identify a signature of the glacial-interglacial cycles. The summary anhysteretic remanent magnetization/ low field susceptibility (ARM/ $X$ ) curve is an indicator of the particle size of magnetite in the sediments (King, this volume). "Coarse" magnetite is deposited during glacial episodes and is represented by lower values of 


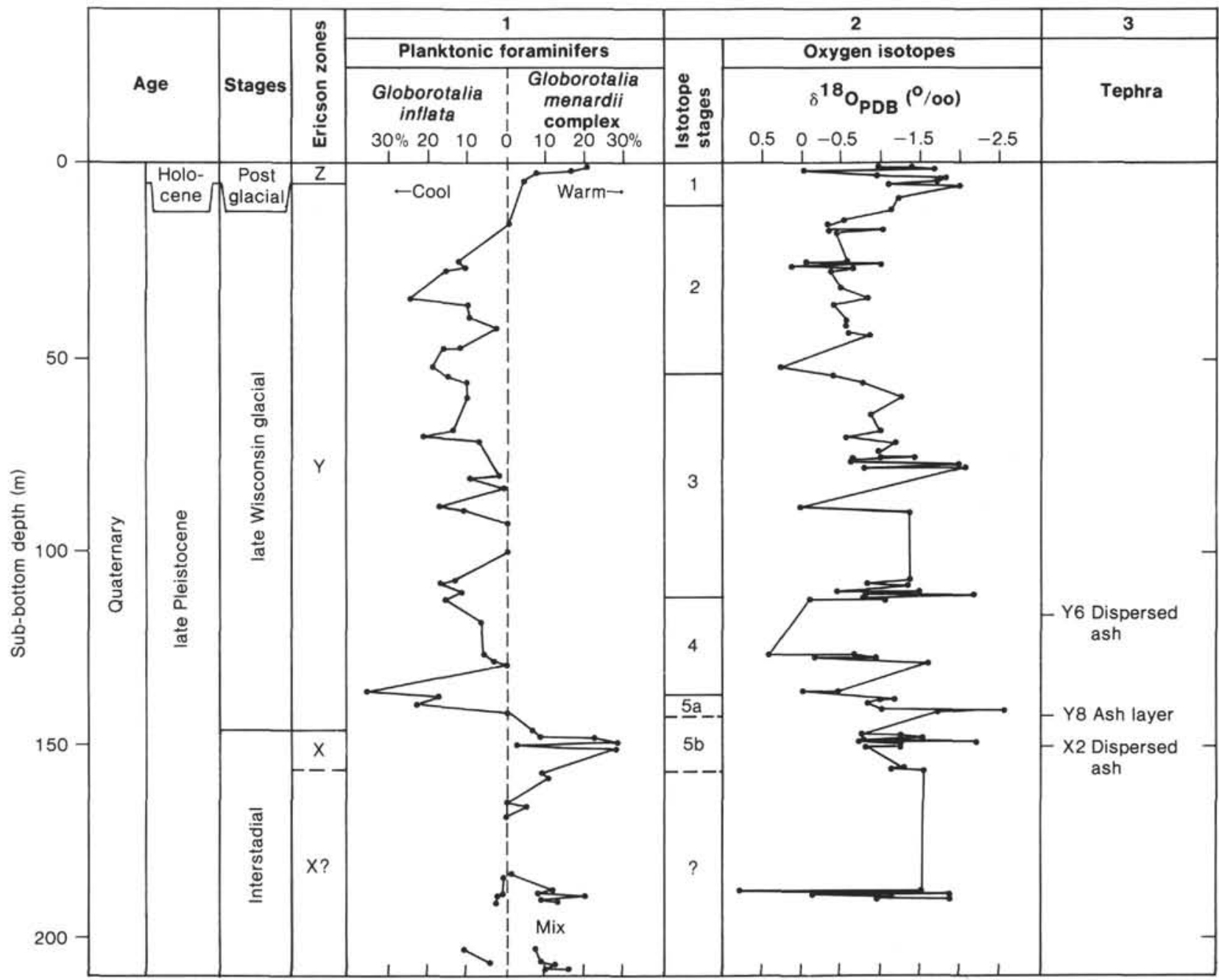

Figure 5. Comparison curves for Site 619, Pigmy Basin. Column 1: combined curve of Globorotalia menardii complex (warm)-increase to right, and G. inflata (cool)-increase to left (Kohl, this volume); Column 2: oxygen-isotope record (Williams and Kohl, this volume); Column 3: dispersed ash and ash layers (Ledbetter, this volume); Column 4: in situ/reworked ratio of calcareous nannofossils (Constans and Parker, this volume); Column 5: percentage $\mathrm{CaCO}_{3}$ in fraction $<63 \mu \mathrm{m}$ (Williams and Kohl, this volume); Column 6: percentage pollen: spruce-hemlock-fir indicates cool temperatures, oak indicates warm temperatures (Heusser, this volume), pine pollen appears to be dominated by cool temperature species. Column 7: Anhysteretic remanent magnetization (ARM) divided by low-field susceptibility $(X)$, high values indicate presence of fine-grained magnetite and low values indicate coarse-grained magnetite. Particle size can be used as an analogue for grain-size variations of the total sediment (King, this volume).

ARM/ $X$ (Fig. 5). Finer-grained magnetite, represented by higher values of $A R M / X$, indicates interglacial periods. An anomalous record occurs below $146 \mathrm{~m}$ sub-bottom, and King suggests that this may be evidence for disturbed bedding. Such an interpretation is consistent with the foraminifer biostratigraphy that shows displaced faunas below $157 \mathrm{~m}$ sub-bottom.

\section{SUMMARY}

1. High deposition rates $(6-11 \mathrm{~m} / 1000$ yr.) during the late Wisconsin glacial (Ericson Zone Y) prevented detailed chronostratigraphic studies at the Mississippi Fan sites.

2. Reworked Cretaceous foraminifers, radiolarians, spore-pollen, and calcareous nannofossils are common at the fan sites during the late Wisconsin glacial (Ericson Zone Y).

3. The Orca Basin (Site 618) was extensively slumped and had to be abandoned as a primary site for chronostratigraphic studies.

4. Pigmy Basin (Site 619) provided an almost undisturbed late Quaternary section above $157 \mathrm{~m}$ sub-bottom. From 157 to $208.7 \mathrm{~m}$, there is an interval of displaced continental shelf sediments.

5. The correlation between biostratigraphy, oxygenisotope stages, and tephrochronology is good at Site 619 and can be related to other holes cored in the Gulf of Mexico.

6. Spore-pollen, total percentage $\mathrm{CaCO}_{3}$, and magnetostratigraphy show potential for use in determining paleoclimates in the late Quaternary intraslope basins. 


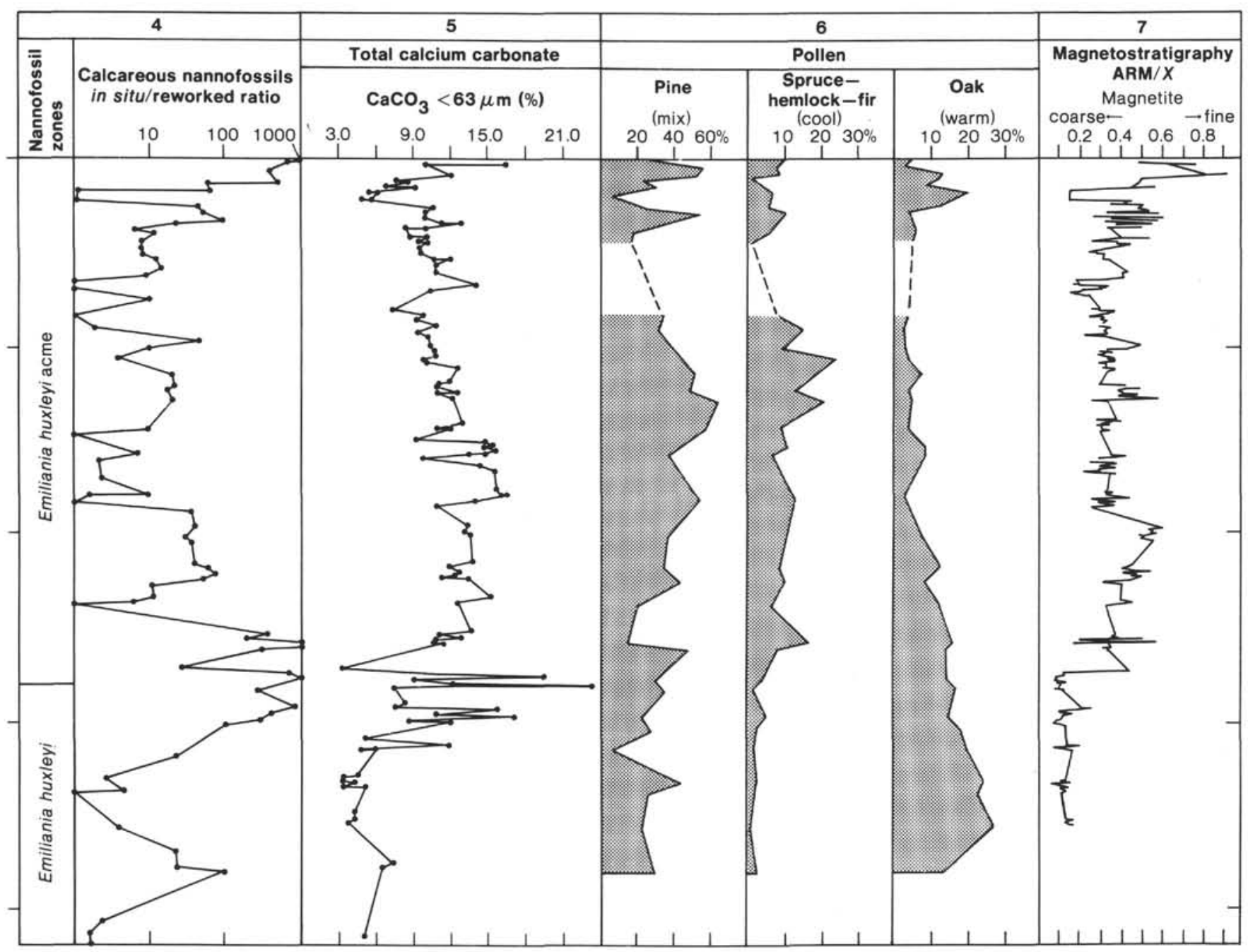

Figure 5 (continued).

\section{ACKNOWLEDGMENTS}

Thanks to Arnold Bouma, Audrey Meyer, and Charles Stelting for critically reviewing the manuscript and to Gail P. Kohl for technical assistance.

\section{REFERENCES}

Boudreaux, J. E., and Hay, W. W., 1967. Zonation of the latest Pliocene-Recent interval. Gulf Coast Assoc. Geol. Soc. Trans., 17: 443-445.

Ericson, D. B., and Wollin, G., 1968. Pleistocene climates and chronology in deep-sea sediments. Science, 162:1227-1234.

Gartner, S., and Emiliani, C., 1976. Nannofossil biostratigraphy and climatic stages of the Pleistocene. Am. Assoc. Pet. Geol. Bull., 60: $1562-1564$.

Kennett, J. P., and Huddlestun, P., 1972. Late Pleistocene paleoclimatology, foraminiferal biostratigraphy and tephrochronology, Western Gulf of Mexico. Quat. Res., 2:38-69.
Kohl, B., and DSDP Leg 96 Shipboard Scientists, 1985. Biostratigraphy and sedimentation rates of the Mississippi Fan. In Bouma, A. H., Normark, W. R., and Barnes, N. E. (Eds.), Submarine Fans and Related Turbidite Systems: New York (Springer-Verlag), pp. 267-273.

Rabek, K., Ledbetter, M. T., Williams, D. F., 1985. Tephrochronology of the western Gulf of Mexico for the last 185,000 years. Quat. Res., 23(3):403-416.

Thierstein, H. R., Geitzenauer, K., Molfino, B., and Shackleton, N. J., 1977. Global synchroneity of Late Quaternary coccolith datums: validation by oxygen isotopes. Geology, 5:400-404.

Williams, D. F., 1984. Correlation of Pleistocene marine sediments of the Gulf of Mexico and other basins using oxygen isotope stratigraphy. In Healy-Williams, N. (Ed.), Recent Advances in Pleistocene Stratigraphy Applied to the Gulf of Mexico: Boston (International Human Resources Development Corp. Press), pp. 65-118.

Date of Initial Receipt: 5 April 1985

Date of Acceptance: 10 October 1985 